地すべり 第25尞 符 2 号

Journal of Japan Landslide Society 25-2 (1988)

\title{
新潟県における積雪期の地すべりについて
}

\section{Landslides in Niigata Prefecture in Snow Season}

\author{
丸 山 清 輝* \\ Kiyoteru MARUYAMA \\ 近 藤 政 司** \\ Masasi KoNDOU
}

\begin{abstract}
Field observation of snow cover related to landslides in the snow season is extremely difficult to perform. Because of this, the mechanism of outbreak of landslides in the snow season has been explained inferentially and has not been clarified based on field observation data. Therefore, the purpose of this report is to clarify the influence of snow cover and snowmelt upon landslides based upon field observation data. The author reviewed the results of snowmelt observation in Arai city, Niigata prefecture, where the Niigata Experiment Station was located, and also calculated the rate of occurrence of landslides in the Jouetsu District in Niigata based on the results. Morever, the author reviewed the mechanism of outbreak of landslides in the snow season by using field observation data obtained at two landslide zones in Niigata Prefecture.
\end{abstract}

\section{まえがき}

北陸地方は，わが国で地すべりが伩も多く発生する地 域である。これは，新第三紀層の泥岩・凝灰岩が広く分 布していることやこの地域が䝉雪地带であることに関係 すると考えられる。积雪と地すべりの因果関係について は，䉼鼬医の神谷地すべりに执いて，長期間の観測を行 い融雪水盐と地すべり移政量との関係を検討した高野 ${ }^{11}$

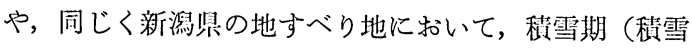
のある期間）に閌隙水任，地下水位等の連続観测を行い， その諸特性について檢討した小川等2) の研究等 ${ }^{32,4), 5)}$ が ある。篗者等も，新潟県砂防課の月別地すべり発生状況 に関する資料と地すべり多発地带の積雪深をもとに，積 雪深の変化と程雪期後半の本格的に雪が解け始めるいわ ゆる融雪期の地すべり発生との関連性について, 新潟県 でも特に融雪期に地すべりが多発する上越地方を取り上 げ検討を行っている6)。

䖽雪期の地すべりについては，䅡雪のため現場観测が 非常に困難なことから，推論的に発生機構等が述べられ ているのが現状であり，現場観測データ等により解明さ れているわけではない。このため, 本報文では, 現場観 测データから穔雪, 融雪が地すべりに与える影響を明ら かにすることを目的として，新潟試験所の所在地である 新鼬県新井市に括いて融雪観測を垁施した結果について 考察し，その結果をるとにして新潟県上越地方に打ける 程雪期の地すべり発生率の算证を試みた。また，䅡雪期

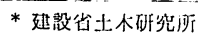

** 利根コンサルタント(排)
の地すべりの発生機槛について, 新潟県下の二カ所の地 すべり地に打ける現場観测データを用いて考察を行った。

\section{1. 新潟県下の地すべり発生状況}

新潟県は，日本における地すべり多発県であると同時 に最も積雪の多い県である。新潟県での積雪と地すべり の関連性については，新潟県砂防課の月別地すべり発生 状沉に関する資料7)を昭和 $24 \sim 62$ 年の39年間についてま とめた図一俍良く現れている。この期間の地すべり発生 件数は 3,134 件であった。月别地すべり発生件数は，4 月が 883 件 (28\%) と一番多く，ついで 7 月の 336 件(11 $\%), 3$ 月の 323 件 (10\%)，5月の 257 件（ $8 \% ）$ の順に なっている。また，積雪期である 12 月から 4 月について は, 3 月拈よび 4 月の積雪が減少する融雪期が仼倒的に 多くなっているものの, 積雪が增加する12月から 2 月に 掛けても地すべりが発生している。この積雪が增加する 期間に発生した地すべりとしては，昭和55年から56年に

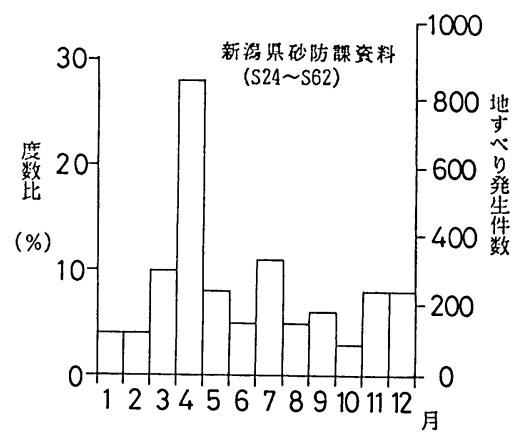

図-1地すべり発生件数 
掛けてのいわゆる56豪雪時に発生した新潟県長岡市の濁 沢地すべり（昭和55年12月30日発生）と新潟県新井市の 上馬場地すべり（昭和56年 1 月 25 日発生）等がある ${ }^{8)}$ 。

以上のことから，積雪期である12月から 4 月の地すべ り発生件数の合計は 1,705 件に達し，全体の $54 \%$ を占め るといら結果となった。したがって, 新潟県に発生して いる地すべりは, 積雪, 融雪の影響を強く受けていると いえる。

\section{2. 融雪観測}

図-1に示したように，積雪期の地すべり発生件数は 3
上の観测項目については, 観測間隔を30分としデータロ ガーに記録した。この他，積雪深は標柱を立て目視によ り，また，雪の密度拈よび積雪重量は，スノーサンプラ 一によりそれぞれ毎日午前 9 時に手観測した。

\section{2 観測結果}

図-4には, 観測結果の中から平均地温, 積算気温(図 -5 に示すように $0^{\circ} \mathrm{C}$ 以上の気温を積算したもの), 最高気 温, 最低気温, 困-3の(c)ライシメーターでの融雪水量, 積雪深, 雪の密度, 積雪重量について示した。ここで, 積雪深, 雪の密度, 積雪重量は, 午前 9 時の観測值を, その他の観測值については，0時〜0時まで 30 分間隔で 月から 4 月の融雪期に多い。このことから，まず， 融雪に関する基礎的な資料を得るために, 新潟試 験所構内 (新潟県新井市) に括いて融雪水量の観 測を行った。

\section{1 観測方法}

融雪水量は, 図-2K示すコンクリート製のライ シメーター $(4 \mathrm{~m} \times 4 \mathrm{~m})$ を, 図-3 亿示すように勾 配20度のモデル斜面上の (a) とその斜面下の (b) 拉 よびモデル斜面から $21 \mathrm{~m}$ 離れた(c)の三力所で製 作し, バケット式流量計により観測した。気象観 测については, パンザーマストに気温, 雨雪量, 湿度, 風向, 風速の計測器を地上 $4 \sim 6 \mathrm{~m}$ の位置 に取り付唯測した。また, 地温は, 地表面下 10 $\mathrm{cm}$ のところに温度計を埋設し観测している。以

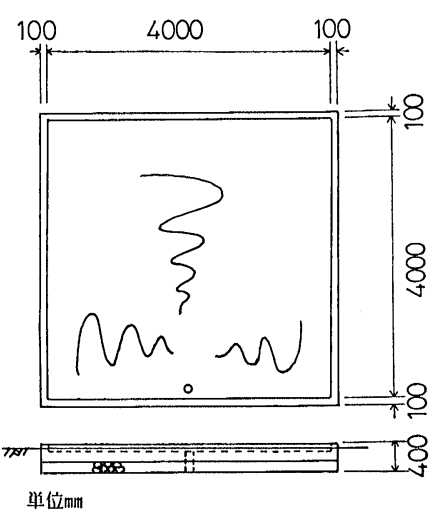

図-2 ライシメーター
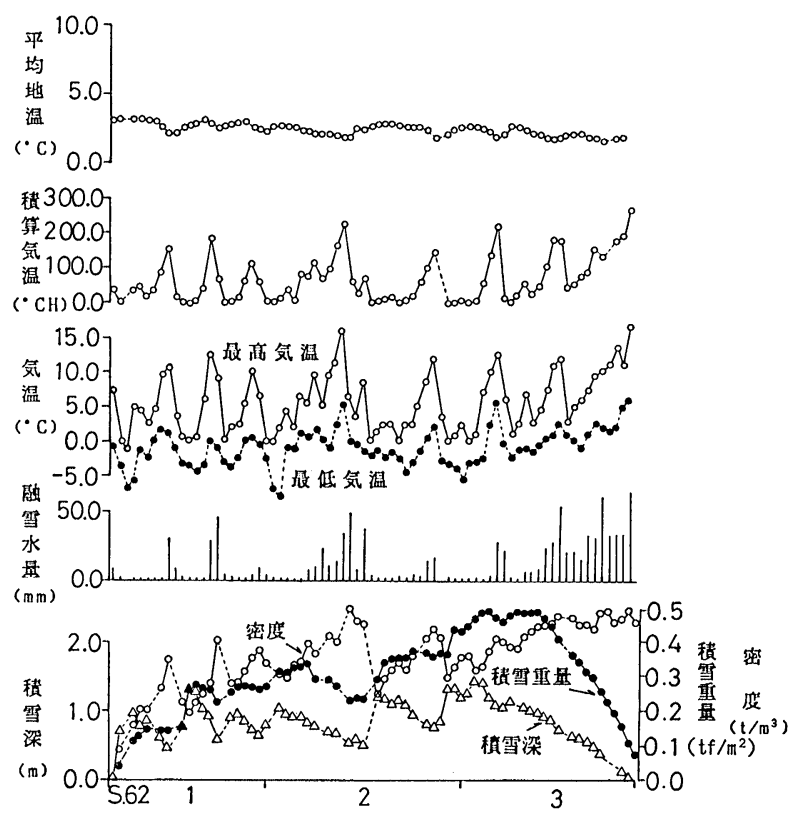

図-4 融雪観測結果

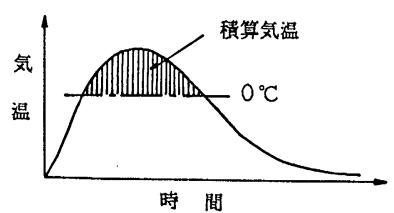

図-5 積算気温

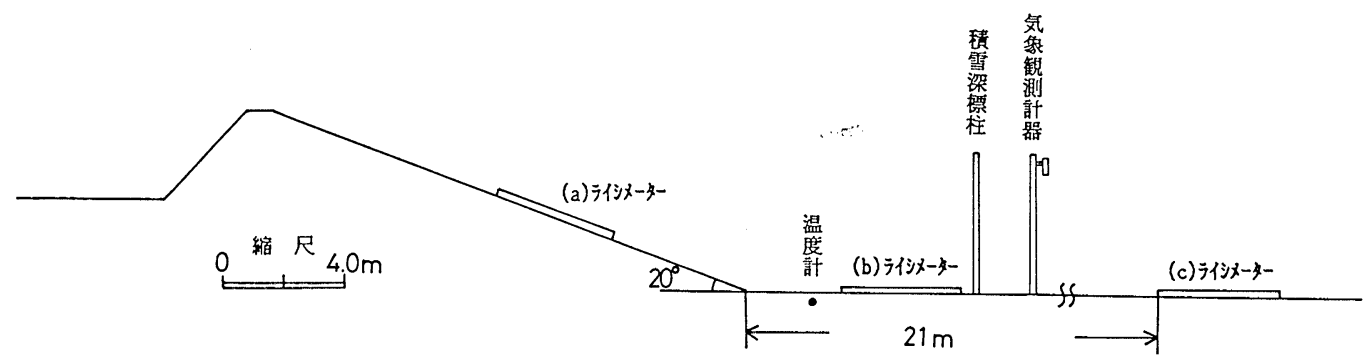

図-3モデル斜面 
地すべり Vol. 25, No. 2 (1988)

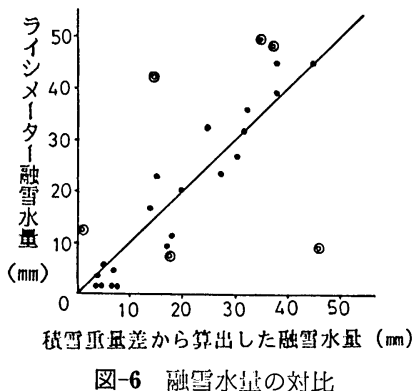

钼测した偩により求めたものである。

図-6 は, 図-4 に示した融雪水量が正確に観测された 值であるか否かをチェックしたものである。つまり， 1 日毎にスノーサンプラーで皘雪深全層の雪を採取して積 雪重量を測定し，前日の值との差をとって日融雪水量を 求めたものと, ライシメーターによって観測した值とを 比較したものである。印以外は 45 度の線付近に位置し ている。この○印は，いずれも降雨があった日の值であ る。これらの値は，図-8に示すように融雪水が積雪層内 の境界面に規制されながら流下するため（詳細は後述す る), ライシメーター鉛直上の融雪水がライシメーター 内に一部が入らなかったり，他の部分から流入したりす る埸合であると考光られる。そして，このようなことは， 降雨があった場合に助長されるように思われる。以上の ような問題は残るが, 今回の大きさが $4 \mathrm{~m} \times 4 \mathrm{~m}$ のライシ メーターで観测した融雪水量は，ほぼ妥当な值と考兄る。 観测結果では, 日融雪水显は 3 月 20 日の $61.0 \mathrm{~mm}$ を
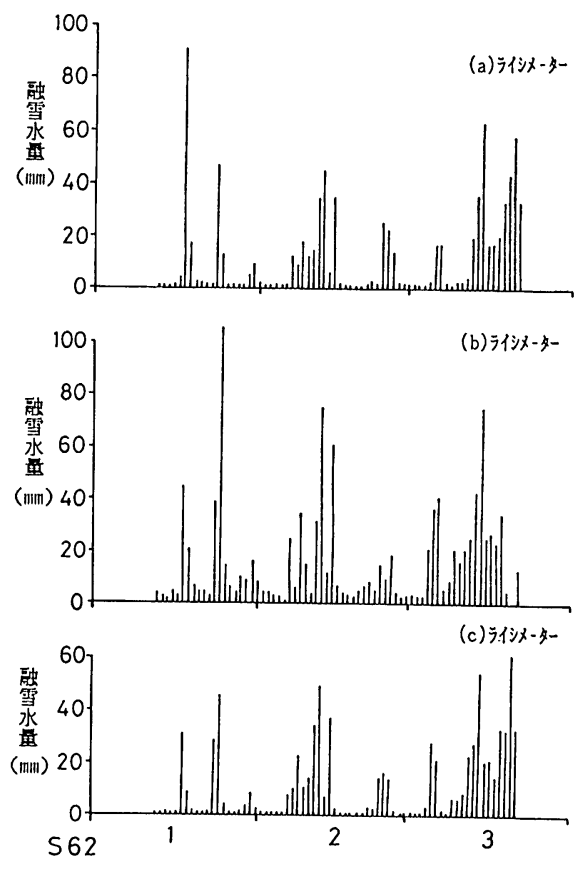

図-7 融雪観测結果の対比
最高に，1月や 2 月に损いても䅡算気温の高い日が継続 すると $50 \mathrm{~mm}$ に近いものがみられる。この他，融雪が 始まった 3 月中旬からの日融雪水量は, $20 \sim 30 \mathrm{~mm}$ 前 後となって和り，3月 9 日から 3 月 21 日までの13日間の 累積では，その值が $343.8 \mathrm{~mm}$ にも達している。また， 積雪期間の平均地温（地表面下 $10 \mathrm{~cm}$ ） は， 湆 $2 \sim 3$ ${ }^{\circ} \mathrm{C} て ゙ あ り ，$ 地温による融雪は非常に少ないものと考えら れる。この他, 積雪重量の变化は, 最大值が䅪雪深の減 少し始める融雪期初期に現れている。また，雪の密度は 稓雪重量の最大值が現れた以後ほぼ一定となり, その平 均値は $0.45 \mathrm{t} / \mathrm{m}^{3}$ となっている。

図-7 には，図-3に示した (a), (b), (c) の位直での融雪 水量の観測結果をまとめて示した。これは, 融雪水量が 斜面と斜面の勾配変換点付近拉よび平地とでは, どの位 違らかを比較したものである。各融雪水量の変化は, 傾 向としては似たものとなっているが，日単位で比較する と値がかなり異なったものとなっている。すなわち，平 地での最大值が 3 月 20 日の $61.0 \mathrm{~mm}$ であるのに対して 勾配20度の斜面では 1 月17日の $91.4 \mathrm{~mm}$ であり，その 斜面下の平地では 1 月 24 日の $105.1 \mathrm{~mm}$ となって拈り, 最大值が出現する日も値も異なっている。また，箖雪期 間中である 1 月 12 日から 3 月 21 日をでの融雪水些の累程 值は, 厸配 20 度の斜面では $892.3 \mathrm{~mm}$, その斜面下の平 地では $1156.5 \mathrm{~mm}$ となり, 平地の $834.2 \mathrm{~mm}$ に対し て, 前者が1.07倍であり後者が1.39倍にもなる。この䢖 いは，図-8に示した稓雪層内の融雪水の流下浸透状況の 調查に現れている。この調查は, 粉末の試薬 (クリスタ ルバイオレット)を図-8に示す散布位圆に直線状に散布

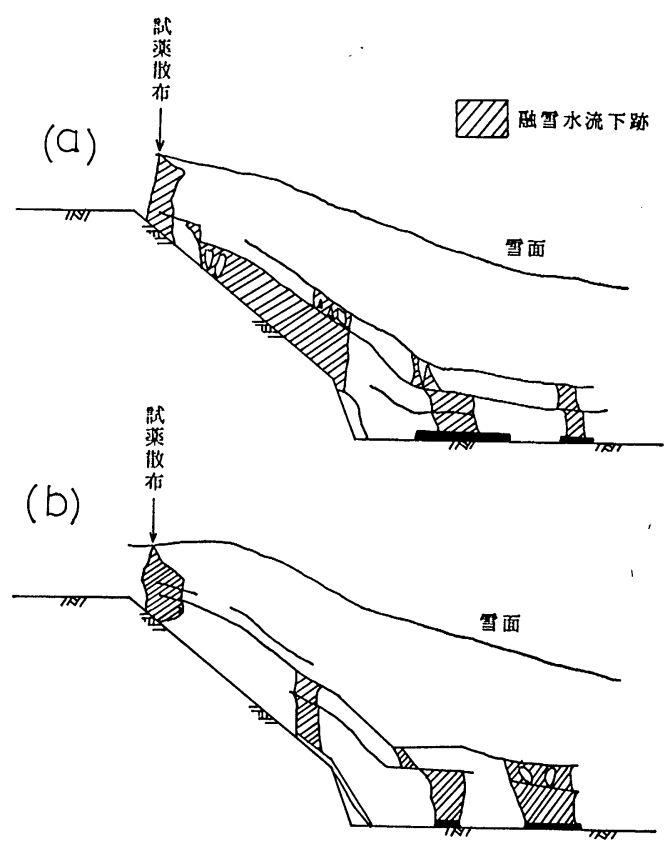

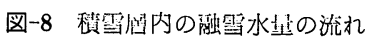




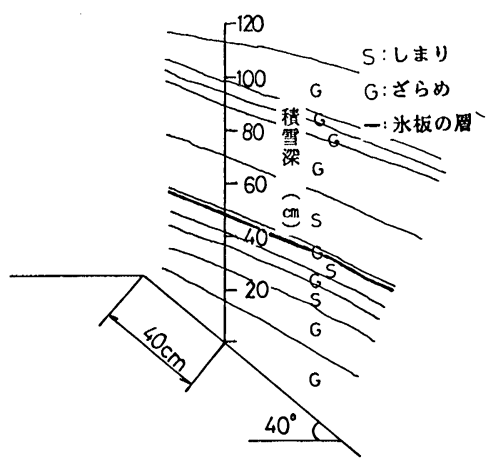

図-9 䠝哥断面

し，試薬で着色された融雪水が積雪層中を流下浸透する 状沉を，積雪層の断面をカット乙観測したものである。 な拈，この時の積雪風の断面は，図-9に示すような状況 となっていた。雪質は, 積雪深 $28 \sim 70 \mathrm{~cm}$ の間にしまり の層が三層みられ，他はざらめ層となっている。また， 積雪深 $49 \mathrm{~cm}$ の積雪層境界面には, 氷板の層がみられた。 融雪水は，図-8に示すように単純に鉛直方向に流下浸透 するのではなく，積雪の層構造（水板等）に規制されな がら層の境界面上を傾斜方向に流下しており，流下範围 は斜面から $3 \sim 4 \mathrm{~m}$ 離れた地点まで及んでいる。また， 融雪水が地表面に達したところは，局部的に集中してい る。このようなことから，斜面拉よび斜面の公配交換点 付近での融雪水は, 積雪の層構造に規制されながら流下 浸透するために，積雪層にキレッのあるところには斜面 上流部の融雪水も流入することになる。この結果, 図-7 に示したように斜面および斜面の勾配変換点付近では， 地表面に達する融雪水量が局部的に多くなり易いことに なる。

以上の観測結果から, 地すべり斜面に拉ける積雪層内 の融雪水の流下状況を推測すると, 斜面勾配の急な部分 での融雪水は, 勾配の緩い部分に集まり易いと考兄られ る。またこのような部分が水の浸透しやすいテンショ ンゾーン等と一致した場合には, 地すべりの発生が一層 促進させられるものと思われる。したがって，地すべり 防止工事では，特に滑落崖拉よび地すべりブロック頭部 付近に地表水排除工等を施工し融雪水の浸透を防止する ことが重要となる。

な扮，図-1の新潟県砂防課の資料によれば 4 月に地す ベり発生件数が多くなっている。しかし，今回の融雪観 測は, 地すべりの発生する山間地に比較すると標高が低 いところに位置する新潟試験所構内であったため，1月 から 3 月までの期間にとどまった。したがって，今後は 地すべりが多発する山間地で融雪観測を実施し, 地すべ りとの関連性について更に検討する予定である。

\section{3. 積算気温の変化と地すべりの発生}

今回の融雪観測の結果では, 融雪水は積算気温の高い 日が継続するとその量が增加する傾向がみられた。この 点に着目して, 新潟県上越地方 (図-11 に範囲を示す) の積雪期に括ける積算気温の変化と地すべり発生につい て, 判別分析(線形判別関数 $)^{9)}$ とより検討を行った。つ まり, ある日から何日か前までの積算気温を説明変数と して，その日に地すべりの発生する確率がどの位かを求 めようというものである。資料としては，昭和46 62年 の間の新潟県砂防課による地すべり災害発生報告7) と位 置が上越地方のほぼ中心となる高田測候所（図-11 に位

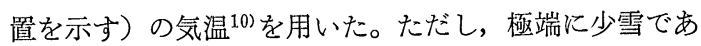
った昭和 $47 ， 48 ， 54$ 年は除いている。この結果，判別分 析には14年間に互る $2 \sim 5$ 月の地すべり発生および非発 生の各々 266 データを用いることにした。な拉，積算気 温は，最高気温と最低気温を用いた（1）（2）式による 三角形近似により求めた ${ }^{11)}$ 。

$$
\begin{aligned}
& D=12\left(T_{\max }+T_{\min }\right) \quad\left(T_{\min } \geqq 0^{\circ} \mathrm{C}\right) \\
& D=12 \frac{T_{\max }}{T_{\max }+\left|T_{\min }\right|} \quad\left(T_{\min }<0^{\circ} \mathrm{C}\right) \\
& D: \text { 積算気温 } \\
& T_{\max }: \text { 最高気温 } \\
& T_{\min }: \text { 最低気温 }
\end{aligned}
$$

判別分析は, 説明変数として当日から 7 日前までの積 算気温を用いて実施し，その中で線形判別関数の係数の 検定を行い，有意水準 $1 \%$ で有意なるのを説明変数とし た。その結果から得られた線形判別関数は，(3) 式とな った。

$$
\begin{aligned}
& 0.00658 X_{4}-4.98238 \\
& Z: \text { 半別得点 } \\
& X_{1}: \text { 当日の積算気温 } \\
& X_{2}: 1 \text { 日前の積算気温 } \\
& X_{3}: 2 \text { 日前の積算気温 } \\
& X_{4}: 5 \text { 日前の積算気温 }
\end{aligned}
$$$$
Z=0.00902 X_{1}+0.00742 X_{2}+0.00730 X_{3}+
$$

また（3）式は確率で表すと（4）式となる12)。

$$
\begin{gathered}
E=\frac{1}{1+\exp (-Z)} \\
E: \text { 地すべり発生率 } \\
Z: \text { 判別得点 }
\end{gathered}
$$

図-10 には，融雪期に比較的地すべり発生件数が多か った（35件）昭和57年の 2 月から 4 月に掛けての計算結 果を示した。地すべりは， 2 月下旬および 3 月上旬の積 算気温の低い時期にも，その発生件数は少ないがみられ る。しかし，多発するようになる時期は，積算気温が上 昇傾向を示す 3 月中旬からである。積算気温から計算さ れた地すべり発生率は，2月から 3 月上旬に掛けては 

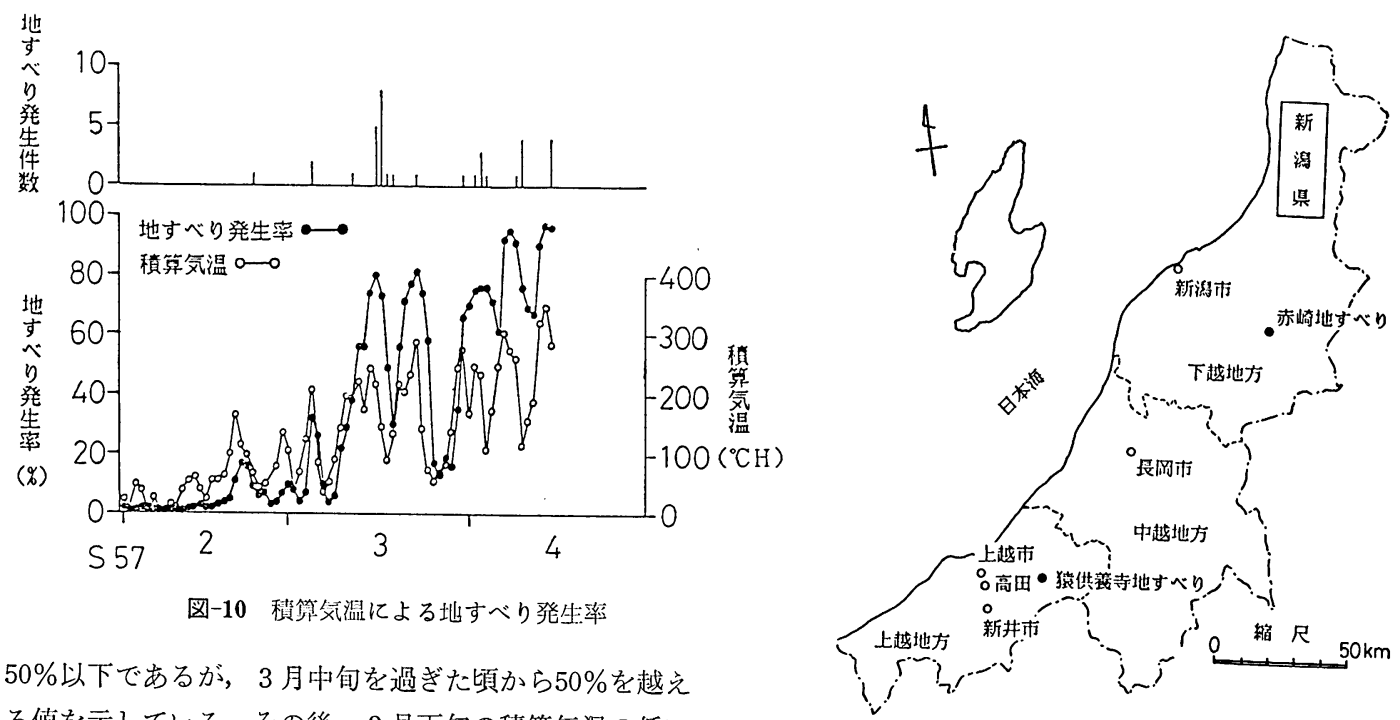

$50 \%$ 以下であるが，3月中旬を過ぎた頃から50\%を越え る値を示している。その後, 3 月下旬の積算気温の低い 時期には $20 \%$ 以下まで低下し，4月からはまた $50 \%$ を越 える値を示している。このような変化は，地すべり発生 件数と対比させると概ね一致していると思われる。した がって, 融雪期の地すべり発生危険度は, 気温データを 用いた判別分析により概略的に知ることができるものと 考える。

\section{4. 皘雪期における地すべりの発生機構}

䉼潟試験所では，地すべり斜面に移動計，間隙水王計 等を設置し，地すべりの動態観測を実施している。本報 文では，その中から図-11 に示す位固にある新鼬県中頸 城郡板食町の猿供荃寺地すべりと新潟県東蒲原郡鹿瀬町 の赤崎地すべりでの榬雪期間の観测データを用いて, 積 雪期に扣ける地すべり発生機構について検討を行った。

\section{1 猿供養寺地すべりの概要 ${ }^{13}$}

猿供荃寺地すべりは，新潟県地方に分布している新第 三紀中新世の第三層にあたる黑色泥岩地带の地すべりで ある。地すべりの形態としては, 頭部では壮年型の弧状 すべりであり，中〜下部は老年型の流動状すべりと考觉 られている14)。

\section{2 猿供養寺地すべりにおける積雪期の移動と間隙 水圧の変化 ${ }^{15)}$}

図-12 には猿供養寺地すべりの観測斜面の平面図を, 図-13 にはその縦断面図をそれぞれ示した。

図-14 の観测結果によると，移動 は11月から 3 月上旬にかけてみられ， 3 月中旬から4月にかけての融雪期 にはみられない。すべり面付近の問 隙水王の変化は，P-11 では，11月 から12月と 2 月下旬から4月にかけ て高くなっている。一方，P-2では， 程雪期間とほぼ同じ12月下旬から 4

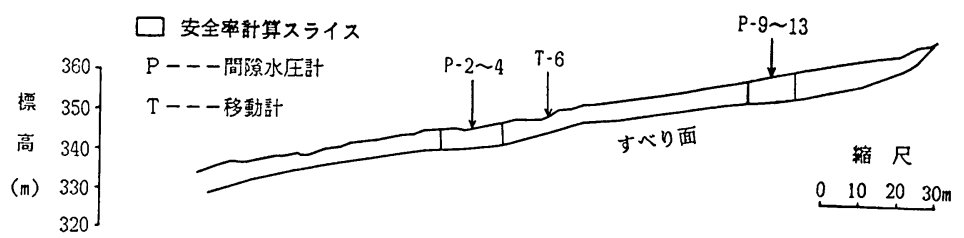

図-13猿供瓷寺地すべり観测斜面断通図 


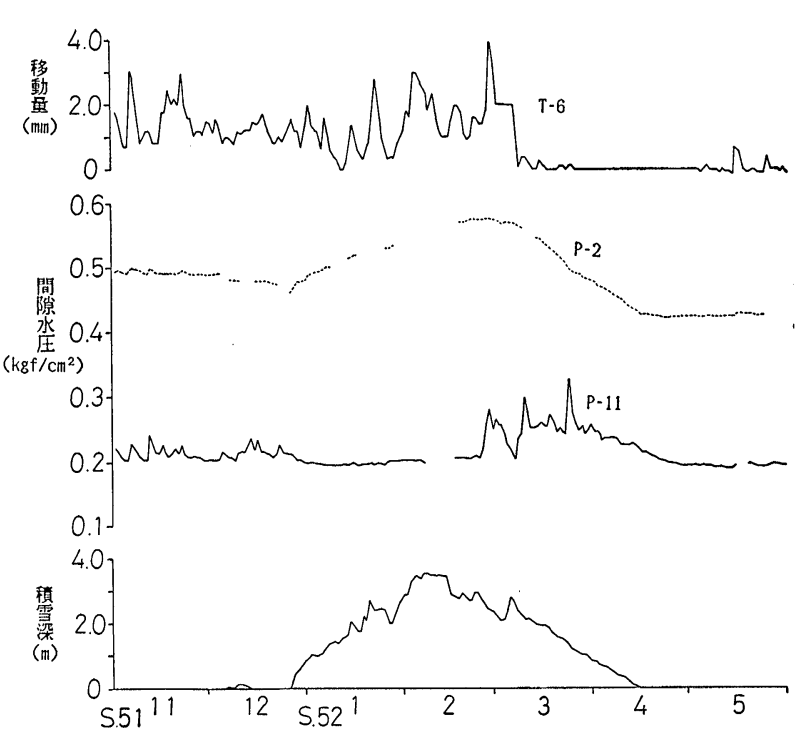

図-14猿供䓹寺地すべり推測結果

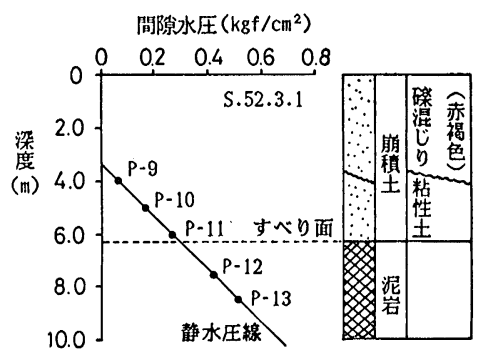

(a)

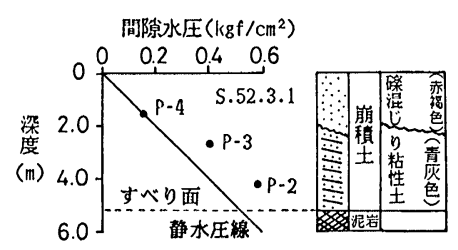

(b)

図-15 鉛直方向の間陌水圧分布

とを示したものと思われる。

図-15 には, 間隙水圧計 P-11と P - 2 が設置されてい る地点での鉛直方向の間隙水圧分布を，昭和 52 年 3 月 1 日について示した。P-11 が設置されている地点の移動 層中の間隙水圧は, 図-15(a) 示すように $\mathrm{P}-9(4.0 \mathrm{~m})$ 〜 P-13 (8.5m) までいずれも静水圧線と一致しているこ とから静水圧分布をしていることが分かる。この地点で の移動層の状沉は, すべり面が深度 $6.5 \mathrm{~m}$ 飞位置し, そ れ以浅の崩積土である硳混じり粘性土は, 地表面から深 度 $4.0 \mathrm{~m}$ 付近まで赤褐色を呈している。一方， P-2 が設 置されている地点の移動層中の間隙水圧は, 図-15(b) に
示すように P-4 (1.6m) が静水圧線と一致して いるものの P-3 $(2.7 \mathrm{~m}), \mathrm{P}-2(4.2 \mathrm{~m})$ について は, いずれる静水圧線より右側位置しているこ とから過鄱間隙水圧となっているのが分かる。 P-2 地点での地盤の状況は, すべり面が深度 5.2 mにあり, すべり面以浅の崩積土である䃯混じり 粘性土は, 地表面から深度 $2.0 \mathrm{~m}$ 付近までは赤褐 色を呈し，それ以深は青灰色となっている。この ことから, 猿供養寺地すべりに抢沙る積雪期の間 隙水圧は, 赤褐色土層内ではその透水性が良いた めに静水圧となり，青灰色士層内では逆に透水性 が悪いため積雪により過㮃間隙水圧となっている ことが分かる。

融雪観測および前述した現場観測結果から地す ベりの発生機構を考察すると, 以下のようになる と考光られる。表-1 は, 四-13 に示す間隙水圧計 が埋設してあるスライスについて, 積雪期前の11 月 12 日之融雪期前の 2 月 20 日拉よび融雪期の 4 月 7 日の安全率を計算した結果である。なお，地すべりブ ロック全体の安全率の計算は, 間隙水圧計の埋設箇所が 二カ所と少ないためここでは行っていない。安全率の計 算は簡便法を用い，間隙水圧はすべり面に等分布に作用 するものとし，積雪は斜面に平均的に分布しているるの とした。また，単位体積重量は現場計測結果から判断し $\tau \gamma_{t}=1.8 \mathrm{t} / \mathrm{m}^{3}$ を用い，土質強度定数はすべり面のリ ングせん断試駼結果である $\phi r^{\prime}=16.7^{\circ}, c r^{\prime}=0 \mathrm{tf} / \mathrm{m}^{2}$ を 用いた ${ }^{16)}$ 。この他, 雪の密度は図-4 に示した融雪観測 結果から判断し, 2 月 20 日については $\gamma_{s}=0.30 \mathrm{t} / \mathrm{m}^{3}, 4$ 月 7 日については $\gamma_{s}=0.45 \mathrm{t} / \mathrm{m}^{3}$ をとれぞれ用いた。安 全率は，P-11スライスでは11月12日に $F_{s}=2.30 ， 2$ 月 20 日に $F_{s}=2.39 ， 4$ 月 7 日に $F_{s}=2.26$ となり，相対 的には積雪期前と融雪期に低く融雪期前では高くなって いる。一方，P-2スライスでの安全率は 11 月 12 日に $F_{s}=$ $1.04,2$ 月 20 日に $F_{s}=0.96,4$ 月 7 日に $F_{s}=1.20$ と なり, 相対的には P-11 スライスとは逆に積雪期前と融 雪期に高く融雪期前では低くなっている。このような安 全率の変化による移動は, 中村等3) の考方方を参考にし て，つぎのように考えることができると思われる。すな わち, 11月から12月の移動は, 積雪前の長雨あるいは初 雪等により P-11 が上昇し，すべり面のせん断強さが低 下したことにより地すべりブロック全体の安全率が低下

表-1 スライスの安全率の変化

\begin{tabular}{|c|c|c|}
\hline & $P-11$ ス $~$ & $P-2$ ス \\
\hline 11月12日 & $F_{s}=2.30$ & $F_{s}=1.04$ \\
\hline 2 月20日 & $F_{s}=2.39$ & $F_{s}=0.96$ \\
\hline 4 月 7 日 & $F_{s}=2.26$ & $F_{s}=1.20$ \\
\hline
\end{tabular}


したためと考えられる。1月から 2 月に掛けては，P-11 が程雪により雨水の浸透がなくなったため下降している が，逆に $\mathrm{P}-2$ が上昇している。この $\mathrm{P}-2$ の上昇は，地 すべりブロック中・下部の移動層の透水性が悪いため, 程雪荷重の增加に移動層の王密が間に合わなくなり, 過 剩間隙水珐が発生したためと考兄られる。このことから， 移動は表-1 によれば P-11スライスの安全率が積雪期前 の11月12日より上昇しているものの，P-2 スライスでは 逆に低下していることから，P-2 スライスではすべり面 のせん断強さがあまり增加せず，稓雪の上昇による地す ベり推力だけが增加する状沉になったことにより地すべ クブロック全体の安全率が低下したためと思われる。3 月から4月については，P-11 が融雪により上昇してい るにも関わらず, 移動は減少している。これは, つぎの ように考光られる。つをり, 表-1 の安全率の变化をみる と, P-2 スライスの安全率は融雪期前の 2 月 20 日上り融 筜期の 4 月 7 日の方が上昇していることから，P-2 の積 雪による過剩間隙水王が，移動督の圧密が徐々に進行す ることと, 融雪による稓雪荷重の減少のため時間ととも に消散するものと考兄れば，すべり面のせん断強さは， この移動畨の压密により 1 月から 2 月の間のものより增 してきたものと思われる。一方, 地すべりブロック全体 では, 積雪が減少しているために地すべり推力む 減少している。この結果, テンションジーンの P-11 が上昇しこのスライスの安全率は低下して いるが，P-2 の位置するコンプレッションゾーン での安全率が上昇していることから，この部分で のすべり面のせん断強さが增してきたため，地す ベりブロック全体の安全率は上昇し移動が減少し

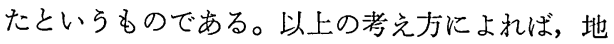
すべり移動層の厚さに対する積雪深の割合がある 程度大きく且つ移動層の透水性が悪い場合は，稓 雪が安全率を低下させ地すべりを発生させる場合 があると思われる。またこのような場合の地す ベり防止工事としては, 地すべりブロック頭部に 执いては融雪水の浸透を防止するために地表水排 除工等を施工し, 中・下部に执いてはすべり面付 近に過剩間隙水圧が発生しないようにするために， すべり面深度に応じて，暗きょ工，横ボーリング 工, 集水井工等を施工することが考兵られる。

\section{3 赤崎地すべりの概要 ${ }^{17)}$}

図-16 には, 赤崎地すべりの平面図を示す。赤 崎地すべり一带には, 新第三紀津川層の最下部層 とされているアルコーズ砂岩と中・上部層の凝灰 岩が分布している。また, 地すべり斜面の北側に 接する赤崎山は，これらを買く流紋岩から成って いる。地すべり地形の特徵としては, 斜面長約 $1,000 \mathrm{~m}$, 幅は地すべり末端部の阿賀野川河岸部
で約 $500 \mathrm{~m}$ を有し, 地すべり未端部を底辺とする二等辺 三角形を星している。また, 面積は約 40 ha（主動域約 25 ha）に達する。地すべり斜面は, 標高 $130 \mathrm{~m}$ 付近で 上部拉よび下部ブロックに分けられ，地表面勾配は全体 的には約 8 度となだらかである。な拉, 地すべり末端部 に括いては，すべり面が阿賀野川の河床面下に達してい る。

\section{4 赤崎地すべりにおける積雪期の移動と間隙水圧 の変化}

図-17 には，赤崎地すべりの主测線縦断面図を示した。 間隙水圧計は, 地すべり斜面頭部 (BV-59-A-18) と中 腹部 (BV-59-B-12) の二カ所のすべり面付近に埋設し, 移動計 (BV-56-6) は中腹部に設置したものである。困一 18の観測結果によると，移動は，12月から1月上旬と 2 月から 4 月上旬にみられ，1月にはみられない。間隙水 圧の変化は，地すべり斜面上部の BV-59-A-18 と中腹 部の BV-59-B-12 では, 前者の上下が激しく後者のそ れは少ない。しかし，全体の变化の傾问は似たものであ る。間隙水圧の高い時期は，12月と 2 月以降であり， 1 月は低くなっている。

図-19 には, 間隙水生計の埋設した近傍のボーリング 柱状図を示した。困-19(a) に示可間隙水俚計 BV-59-A-

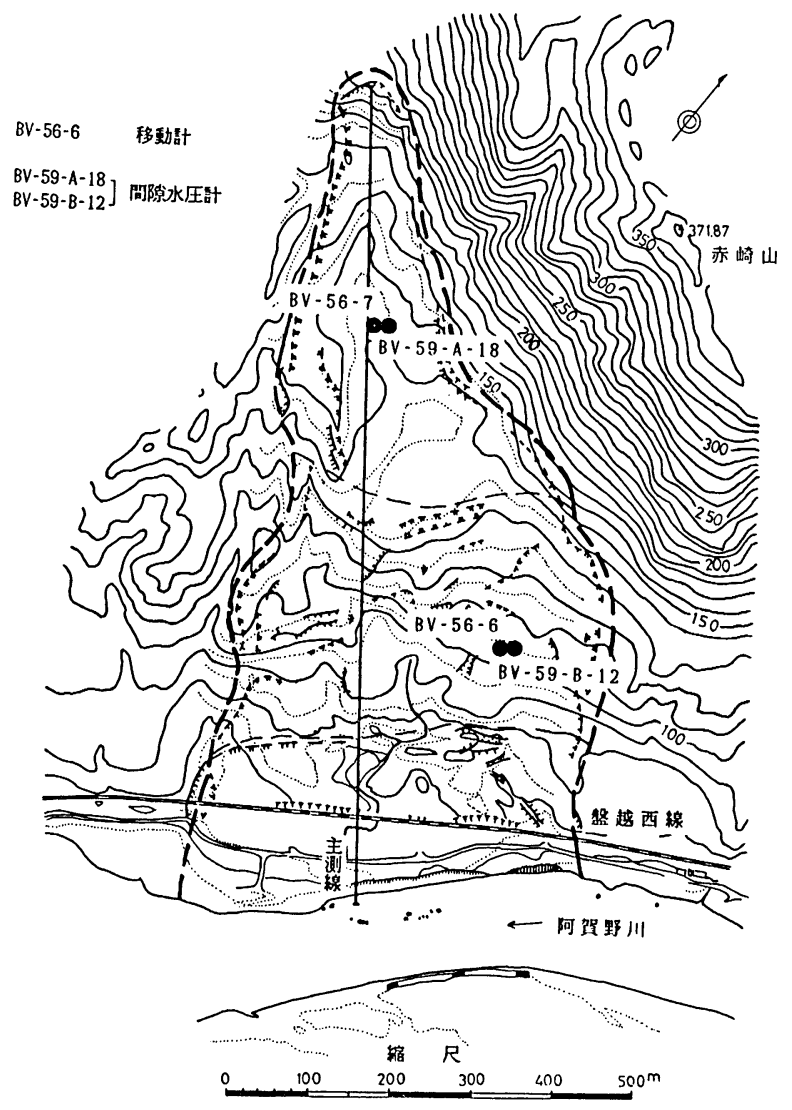

図-16 赤崎地すべり平面図 


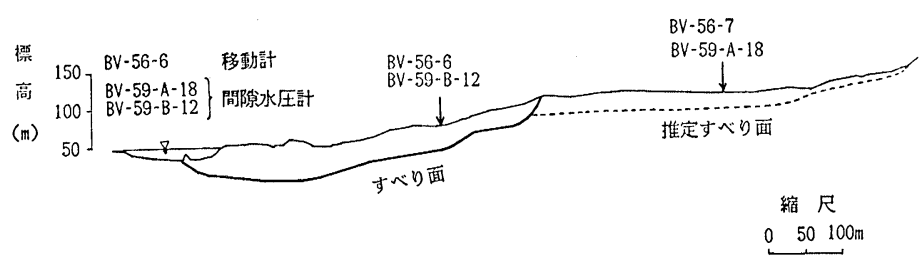

図-17 赤崎地すべり主测線断面図

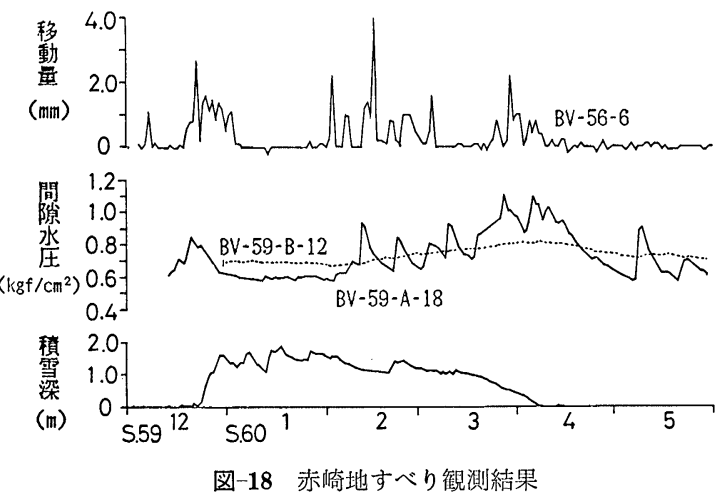

18 付近の BV-56-7 は, 地表面から間隙水圧計の埋設深 度 $18.0 \mathrm{~m}$ を含む $20.7 \mathrm{~m}$ まで磁混じり粘性土となってお り, 色調は黄褐色を呈している。また, 掘削時には孔内 崩壊が激しかったことからガラ場を形成する地層となっ て沏り，透水性が良い土層構成であると思われる。一方， 図-19(b) 亿示吉間隙水圧計 BV-59-B-12 付近の BV-56-6 そついては, 前者と同様に地表面から間隙水圧計の埋設 深度 $12.0 \mathrm{~m}$ を含む $12.9 \mathrm{~m}$ まで碯混じり粘性土であり, 色調も黄褐色を是している。しかし, 深度 $8.8 \sim 12.9 \mathrm{~m}$

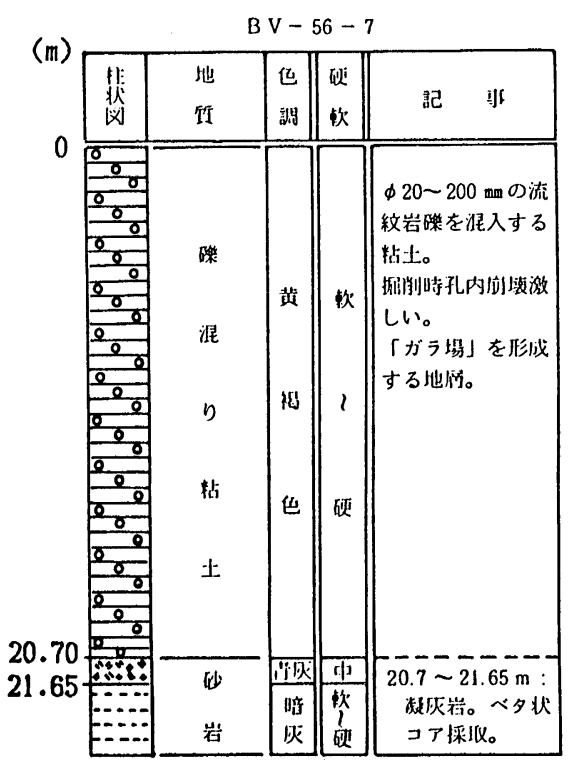

(a)
までは, 強風化凝灰岩および砂岩転石を 含有する粘上となって招り，間隙水圧計 BV-59-A-18 の地点より透水性が悪い と思われる。このことは, 間隙 水生計 BV-59-A-18 の変化が激しいのに対し て，BV-59-B-12 の変化が緩慢であると 言う違いとなって現れているものと考兄 る。

この地すべりについても, 観測結果から地すべり発生 機構を考察すると，つぎのようになると思われる。すな わち，12月の移動については，積雪前の長雨あるいは初 雪等により地すべり斜面全体の間隙水圧が上昇し，すべ り面のせん断強さが低下したためと考えられる。また， 1 月の移動の減少については, 積雪により雨水の浸透が なくなり地すべり斜面全体の間隙水圧が低下し，すべり 面のせん断強さが增したためと思われる。2 月から 4 月 については，融雪が始まり地すべり斜面全体の間隙水圧 が上昇し，すべり面のせん断強さが低下し移動したと考 えられる。なお，赤崎地すべりでは前述した移動層の地 盤状況のため，猿供養寺地すべりにみられた積雪による 過剩間隙水圧の発生と移動はみられない。

\section{おわりに}

本報文では, 現場観測データをるとに積雪, 融雪が地 すべりに与える影響を明らかにするために，融雪観測を 実施し，その結果をもとにして新潟県上越地方における 積雪期の地すべり発生率の算出を試みた。また，積雪期 の地すべり発生機構について, 新潟県下の二カ所の地す

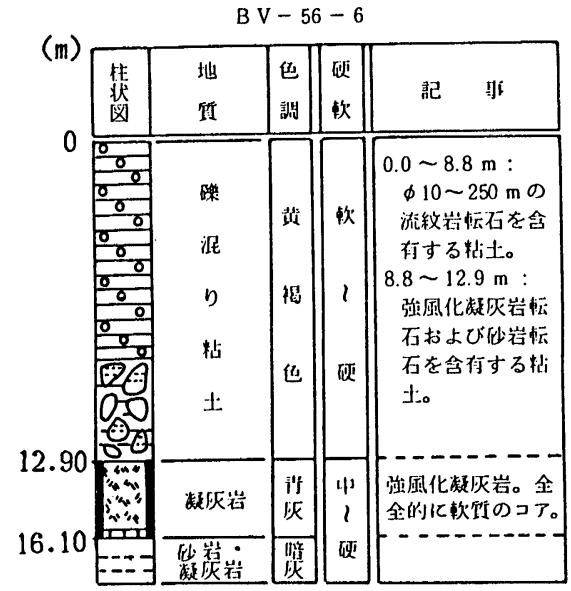

図-19閻隙水圧観测地点近傍の地盤状沉 
ベり地に打ける現場観测データを用いて考察を行った。 その結果を要約すると以下のと扣りである。

(1) 䉼潟県に発生している地すべりは, 䉼鼬県砂防課 の月别地すべり癷生状沉に関する资料を壯和 $24 \sim 62$ 年の 39年間についてまとめた結果によると，糟雪期である 12 月から4月の地すべり発生件数は, 全体の $54 \% を$ 占め, 积雪，融雪の影響を強く受けている。

(2) 融雪水留の観測結果では，1月や 2 月においても 䅡算気温の高い日が継続すると $50 \mathrm{~mm}$ に近いものがみ られた。

(3) モデル斜面の融雪観测結果によれば，融雪水は斜 面扣よび斜面の勾配交換点付近では，積雪層の境界面に 規制されながら流下漫透するために，地表面に達する水 显が局部的に多くなり易いことが分かった。

(4) 新潟県上越地方に括ける積算気温の変化と地すべ り発生について判別分析 (線形判別関数) により検討し た結果では, 気温データを用いて（3），(4) 式により地 すべり発生危険度を概略的に知ることができた。

(5) 雪が地すべり斜面に与える影響として, 積雪荷重 によるすべり面の間隙水圧の上昇と融雪によるすべり面 の間隙水王の上昇の二つによるものがあげられているが, 現笏観測結果から前者については猿供養寺地すべりで追 認し，後者については赤崎地すべりで確認した。

吱後に，本調查をまとめるにあたり，多くの御助言を いただいた建設省上木研究所新潟試験所下村所長ならび に急傾斜地崩塤研究室吉松室長 (元 新鼬試験所長) に厚 く感謝いたします。

\section{参考文献}

1）演野奀大：地卞べりと防此法，地球出版，1961.

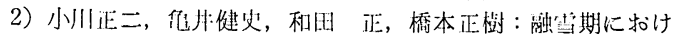

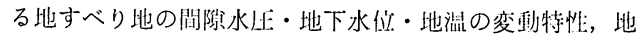
すべり, Vol. 23, No. 3, pp. 21〜27, 1986.

3）中村浩之, 白不吉信：整の地すべりに与える影饗について, 地すべり, Vol. 10, No. 1, pp. 6〜16, 1973.

4）清山清道，中侯三郎，小川正二：新潟県に於ける地すべり

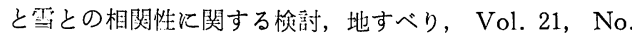
3, pp. 11-16, 1984.

5）江口正紀：融䰹に伴う土砂災寒（坄近の地すべり災㕩を中 心として), 第14回砂防学会シンポジウム概要集, pp. 61〜 $71,1981$.

6)山内 修, 近藤政司, 丸山湤煇 : 新潟県上越地方の融雪地 すべり特性，上木技術資料，Vol. 26， No. 9, pp. 29 34, 1981.

7) 新潟県砂防課資料.

8）松山完：新潟県・長岡市濁沢，新井市上歌場の地すべり 災害について，地すべり，Vol. 18，No. 2, pp. 38〜 41, 1981.

9）田中 蕒, 垂水共之, 脇本和昌 : パソコン統計解析ハンド ブック II 多変量解析編, 共立出版株式会社.

10）新潟気象台：新潟県気象月報.

11）加藤 徹, 佐藤是三: 融雪冝算定に用いる稓算気温を求め る簡便式について，第17回自然災害シンポジウム, 1980.

12）柳井啨夫, 高根芳雄 : 多編量解析法, 朝合苗店

13）新潟試験所：猿供算寺地すべり調查報告谋(II)，士木研究 所资料，第 2614 号，昭和63年 3 月.

14）山田㴊二, 渡 正亮，小橋澄治：地すべり・斜面崩壊の実 態と対策, 山海堂, 1971.

15）新潟試験所：猿供養寺地すべり調查報告㫖一资料編（その 2 )一，士木研究所资料，第 2393 号，昭和 61 年 8 月.

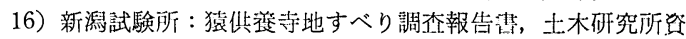
料, 第 1770 号, 昭和 57 年 3 月.

17）新潟試験所：赤崎地すべり調查報告蓝，士木研究所资料， 第2499号, 昭和62年 5 月.

（原稿受理日 吗和63年 7 月27日） 